\title{
EKSPOR DAGING SAPI KANADA PASCA KEBIJAKAN COUNTRY OF ORIGIN LABELLING AMERIKA SERIKAT TAHUN 2009-2015
}

\author{
Harun Umar ${ }^{1}$, Saphira Evani ${ }^{2}$ \\ ${ }^{1}$ Program Pascasarjana Ilmu Politik, Universitas Nasional \\ ${ }^{2}$ Program Studi Ilmu Politik, Universitas Nasional \\ email : heron9300@gmail.com, ssaphiraevanii@gmail.com
}

Korespondensi : ssaphiraevanii@gmail.com

\begin{abstract}
The presence of foreign policy has a big impacts on the implementation of the state life of every international actor, especially for the super power countries such as the United States. These conditions make the United States have control over other countries by taking actions that only benefit one side, such as protection. The Country of Origin Labeling (COOL) policy is a form of protection carried out by the United States with the aim of limiting the amount of beef imported from Canada to enter the United States market because it has been contaminated with Bovine Spongiform Encephalopathy (BSE) or mad cow diseases which is very dangerous for human health. The implementation of the COOL succeeded in making Canadian beef exports decrease and causing a deficit in the country's trade balance. Therefore, Canada must have an efforts to maintain the stability of its beef exports so that it can benefit the Canadian economy and achieve the national interest of the country.
\end{abstract}

Keywords: country of origin labelling, beef export, canada, national interes, america serikat

\begin{abstract}
Abstrak
Kehadiran kebijakan luar negeri memiliki pengaruh yang besar bagi pelaksanaan kehidupan bernegara setiap aktor internasional, terutama bagi negara super power seperti Amerika Serikat. Kondisi tersebut membuat Amerika Serikat memiliki kontrol terhadap negara lainnya dengan melakukan tindakan yang hanya menguntungkan sebelah pihak saja, seperti melakukan proteksi. Kebijakan Country Of Origin Labelling (COOL) (2011) merupakan salah satu bentuk proteksi yang dilakukan oleh Amerika Serikat dengan tujuan untuk membatasi jumlah daging sapi impor dari Kanada yang masuk ke pasar Amerika Serikat karena telah terkontaminasi oleh penyakit Bovine Spongiform Encephalopathy (BSE) atau sapi gila yang sangat berbahaya bagi kesehatan manusia. Implementasi kebijakan COOL tersebut berhasil membuat jumlah ekspor daging sapi Kanada menurun sehingga menyebabkan defisit pada neraca perdagangan negaranya. Oleh karena itu, Kanada harus memiliki upaya untuk menjaga stabilitas ekspor daging sapinya sehingga dapat memberikan keuntungan bagi perekonomian Kanada serta tercapainya kepentingan nasional negara.
\end{abstract}

Kata kunci: country of origin labelling, ekspor daging sapi, kanada, kepentingan nasional, amerika serikat 


\section{PENDAHULUAN}

Perdagangan internasional memiliki andil yang besar dalam pertumbuhan ekonomi dan peningkatan kesejahteraan suatu negara. Salah satunya adalah melalui kegiatan ekspor dan impor, yang kerap dilakukan oleh suatu negara untuk memenuhi permintaan suatu negara terhadap komoditas yang dihasilkan di luar negeri. Kegiatan ini dapat dilakukan dalam berbagai sektor, termasuk sektor pertanian, khususnya pada produk daging sapi.

Daging sapi menjadi komoditas pangan yang selama ini memberikan andil yang cukup besar terhadap pemenuhan gizi masyarakat guna menopang pembangunan sumber daya manusia sehingga negara-negara pun mulai melakukan ekspor impor untuk memenuhi kebutuhan yang tidak cukup dan tidak dapat diproduksi oleh negaranya sendiri. Salah satunya adalah Kanada.

Kanada merupakan salah satu negara dengan kekuatan ekonomi yang cukup besar di dunia. Menurut data statistik yang dikeluarkan oleh World Bank, nilai Gross Domestic Product (GDP) Kanada mengalami pertumbuhan yang signifikan dengan menempati angka US\$ 1.371 triliun pada tahun 2009 dan US\$ 1.842 triliun pada tahun 2013 yang didorong oleh banyaknya kegiatan perdagangan yang telah dilakukan oleh Kanada, terutama pada ekspor produk pertanian dan sumber daya alam.

Kedudukan Kanada sebagai salah satu pengekspor utama produk pertanian dunia telah membuat negara tersebut menjadi sasaran mitra dagang bagi negaranegara di dunia, termasuk Amerika Serikat. Kedua negara telah menjalin hubungan bilateral sejak cukup lama dan menjadi salah satu hubungan perdagangan terbesar di dunia. Hubungan perdagagan bilateral tersebut semakin dipererat dengan adanya Canada United States Free Trade Agreement (CUSFTA) yang dibentuk pada tahun 1989.

Sama halnya seperti Kanada, kekuatan ekonomi Amerika Serikat juga dibangun melalui kegiatan perdagangan produk pertanian seperti daging sapi. Menurut data dari United States Department of Agriculture (USDA), produksi daging sapi Negeri Paman Sam tersebut pada tahun 2015 mencapai 11,32 juta ton dan berkontribusi sebesar 19,25\% pada produksi dunia. Selain itu, Amerika Serikat juga dikenal sebagai negara dengan tingkat populasi paling tinggi di dunia.

Namun kondisi tersebut sempat diresahkan oleh tingginya angka kematian di Amerika Serikat pada tahun 2009 hingga 2015 yang disebabkan oleh penyakit Creutzfeldt-Jakob (CJD). USDA mengidentifikasi bahwa penyakit tersebut muncul karena banyaknya konsumen yang mengkonsumsi produk daging sapi impor yang terkontaminasi penyakit Bovine Spongiform Encephalopathy (BSE) atau sapi gila. Produk daging sapi tersebut diketahui berasal dari Kanada.

Atas dasar kesehatan dan keamanan pangan itulah, maka USDA mulai memperketat aturan terkait perdagangan dibidang pertanian dengan mengamandemen the Agricultural Marketing Act of 1946 dan menjadikan beberapa covered commodities sebagai salah satu persyaratan masuknya barang-barang impor ke Amerika Serikat. Peraturan tersebut kemudian menjadi poin baru dalam regulasi tersebut sebagai Country of Origin Labelling (COOL). 
Kebijakan COOL adalah kebijakan yang mengatur tentang pelabelan negara asal produk-produk impor livestock, seperti produk daging (daging sapi, daging babi, daging ayam, dan daging kambing), produk buah-buahan dan sayuran, kacangkacangan serta rempah-rempah yang masuk ke pasar Amerika Serikat. Kebijakan proteksi ini mulai berlaku sejak tahun 2009 ketika penyakit BSE mulai muncul dan menyebar di Kanada. Kebijakan ini dilakukan melalui pencantuman label "product of...." atau "made in...." pada setiap produk impor yang masuk ke pasar Amerika Serikat.

Hadirnya kebijakan COOL ini telah membuat Kanada kesulitan untuk memasarkan produk daging sapi mereka ke negara yang menjadi sasaran utama pasar komoditas tersebut. Dengan lebih dari 75\% dari keseluruhan ekspor Kanada yang masuk ke Amerika Serikat, maka hadirnya kebijakan COOL telah membuat kegiatan perdagangan Kanada ke Amerika Serikat menjadi terganggu. Kondisi ini pula dapat mengancam kestabilan dan pertumbuhan perekonomian suatu bangsa. Dalam menanggapi hal ini, Kanada tentunya memiliki berbagai upaya untuk meminimalisir kerugian yang didapat dari adanya kebijakan COOL ini.

\section{Teori Kunggulan Komparatif}

Teori ini berasal dari seorang pakar ekonomi politik Inggris, David Ricardo dan pertama kali diperkenalkan pada awal abad ke-19. Dalam bukunya On the Principle of Political Economy and Taxation ( $2^{\text {nd }}$ Edition) yang diterbitkan pada tahun 1819, Ricardo menjelaskan bahwa keunggulan komparatif (comparative advantage) adalah proposisi bahwa suatu negara dapat mengimpor komoditas tertentu meskipun dapat menghasilkan jumlah yang sama secara internasional dengan biaya riil yang lebih rendah daripada negara pengekspor.

Berdasarkan pemikiran tersebut, John Sturart Mill (1885) kemudian membentuk pandangannya sendiri mengenai ekonomi politik yang dituangkan ke dalam sebuah buku berjudul Principles of Political Economy. Dalam buku tersebut, beliau menguraikan gagasan Adam Smith dan David Ricardo terkait perdagangan internasional sehingga menghasilkan sebuah pemikiran baru mengenai skala ekonomi, biaya peluang (opportunity cost), dan keunggulan komparatif (comparative advantage) dalam perdagangan. Menurutnya, suatu negara masih dapat menikmati keuntungan dalam perdagangan walaupun negara tersebut kurang efisien dan tidak memiliki keunggulan absolut (absolute advantage) terhadap negara lain.

Hal tersebut dapat terjadi karena yang menentukan suatu keuntungannya bukanlah biaya mutlak (absolute cost) dalam produksi, melainkan biaya peluang (opportunity cost). Biaya peluang (opportunity cost) merupakan biaya yang dikorbankan untuk sasaran atau tujuan yang lain. Biasanya biaya peluang ini terjadi karena adanya pilihan yang ditinggalkan akibat memilih pilihan lain yang dianggap memberikan keuntungan lebih.

Selain itu, teori ini juga mendemonstrasikan prinsip bahwa suatu negara akan mengekspor barang dan jasa yang dapat menghasilkan biaya peluang (opportunity cost) yang rendah dengan menjual produk ke negara yang memiliki harga jual yang tinggi. Sebaliknya, suatu negara akan mengimpor barang dan jasa 
yang dapat menghasilkan biaya peluang (opportunity cost) yang tinggi atau dengan kata lain akan membeli produk dengan harga yang lebih murah.

\section{Teori Kepentingan Nasional}

Dalam ranah internasional, negara memainkan peran sebagai aktor yang mengambil keputusan dalam upaya mencapai kepentingan nasional suatu negara. Kepentingan nasional secara konseptual digunakan untuk menjelaskan perilaku politik luar negeri suatu negara. Scott Burchill (2005), dalam bukunya The National Interest in International Relations Theory, melakukan sebuah analisis tentang bagaimana perspektif-perspektif hubungan internasional dalam memahami kepentingan nasional. Salah satunya dilihat dari perspektif liberalisme.

Menurut pandangan liberalisme, kepentingan nasional bukan hanya terletak pada keamanan negara saja, melainkan pada stabilitas ekonomi dan pasar yang harus menjadi acuan. Scott Burchill menjelaskan bahwa kepentingan nasional yang ingin dicapai oleh suatu negara adalah berjalannya mekanisme pasar sehingga individu di masyarakat dapat melakukan aktivitas ekonomi dengan tenang.

\section{Gambaran Umum Kebijakan Country Of Origin Labelling (COOL)}

Kebijakan COOL merupakan kebijakan pelabelan yang mengharuskan pengecer seperti toko bahan makanan dan supermarket untuk memberikan informasi kepada para konsumen mengenai negara asal makanan tertentu, terutama produkproduk impor livestock yang masuk ke pasar domestik. Produk livestock dalam kebijakan COOL tersebut biasa disebut dengan covered commodities, yaitu produkproduk yang memang diwajibkan memiliki keterangan label negara asal pada kemasannya. Adapun beberapa produk yang termasuk ke dalam kategori covered commodities adalah sebagai berikut:

1. Daging potong, meliputi daging sapi (termasuk daging sapi muda), daging babi, daging domba, daging kambing, dan daging ayam

2. Daging giling, meliputi daging sapi, daging babi, daging domba, daging kambing, dan daging ayam.

3. Buah dan sayuran.

4. Ikan dan kerang budidaya.

5. Kacang-kacangan, meliputi kacang tanah, kemiri, dan kacang macadamia.

6. Rempah-rempah, seperti gingseng.

Kebijakan COOL dibentuk oleh United States Department of Agriculture (USDA) dan diharapkan dapat mempermudah para konsumen ketika akan melakukan kegiatan pembelian. Tujuan utama dibentuknya kebijakan COOL ini adalah untuk memberikan informasi kepada konsumen terkait negara asal produkproduk agrikultur yang akan mereka konsumsi sehingga para konsumen dapat mengetahui dan memutuskan lebih memilih untuk mengkonsumsi produk lokal atau produk impor. Melalui kebijakan COOL ini, pemerintah Amerika Serikat bermaksud untuk mengatur jalannya perdagangan atas produk pertanian dan peternakan mereka. Adapun yang menjadi sasaran Amerika Serikat dalam kebijakan ini adalah konsumen dan petani atau peternak. 
Implementasi kebijakan COOL ini dilakukan melalui pemberian label "product of..." atau "made in..." pada setiap produk impor yang masuk ke pasar Amerika Serikat. Bentuk pelabelan tersebut dapat dibuat melalui proses ketik, cetak ataupun tulis tangan. Dalam 7 CFR Part 65. 400 (a) of the 2009 Final Rule (AMS) dijelaskan bahwa pemberitahuan kepada konsumen dapat melalui pemberian label, plakat, stempel, stiker, pita, twist tie, tanda, serta pin tag pada seluruh covered commodities yang masuk ke pasar Amerika Serikat.

Selain itu, pemberian label negara asal produk makanan juga harus dibedakan berdasarkan proses produksi yang telah dilakukan oleh produk tersebut. Adapun lima kategori yang menjadi faktor pembeda tersebut adalah sebagai berikut

1. Kategoti A, United States Country of Origin.

2. Kategoti B, Multiple Countries of Origin.

3. Kategori C, Imported for Immediate Slaughter.

4. Kategori D, Foreign Origin.

5. Kategori E, Grounded Meat Products.

Namun dalam pelaksanaannya, terdapat dua entitas yang dibebaskan dari aturan terkait kebijakan COOL ini. Sesuai dengan The Perishable Agricultural Commodities Act of 1930 (the PACA) dua entitas tersebut adalah para petani dan perusahaan layanan makanan. Petani tidak dianggap sebagai pengecer karena mereka menjual produk pertanian yang diproduksi dan dihasilkan sendiri yang kemudian akan mereka jualkan secara langsung kepada konsumen tanpa melalui perantara.

Selain itu, perusahaan layanan makanan seperti restoran, kafetaria, kedai makanan dan minuman, bar, serta lounge juga tidak termasuk ke dalam kategori pengecer. Hal tersebut dapat terjadi karena produk yang mereka jual secara langsung kepada konsumen juga merupakan hasil olahan mereka sendiri yang kemudian menjadi sebuah makanan cepat saji yang siap dihidangkan. Hal inilah yang membuat mereka tidak harus mematuhi ketentuan COOL.

\section{Kebijakan Country Of Origin Labelling (COOL) Dalam Perdagangan Internasional}

Kebijakan luar negeri sering kali dijadikan oleh negara untuk mencapai kepentingan nasional negaranya. Tak heran jika negara-negara dengan power yang besar mulai memanfaatkan sebuah kebijakan untuk melakukan tindakan yang hanya menguntungkan sebelah pihak seperti proteksionisme yang dapat menghambat jalannya perdagangan internasional melalui penetapan tarif beamasuk impor, pembatasan kuota, pemberian subsidi, ataupun sejumlah hukum nasional lainnya sebagai instrumen untuk menekan jumlah impor atau bahkan dapat melarang masuknya impor ke suatu negara.

Amerika Serikat termasuk salah satu negara yang menggunakan kebijakan luar negeri sebagai instrumen untuk melakukan proteksi. Kebijakan itu secara tidak langsung menjadi bentuk hambatan baru berupa hambatan non-tarif yang digunakan sebagai salah satu senjata utama mereka untuk melakukan pembatasan dan pelarangan masuknya impor ke negaranya. 
Besarnya kekuatan ekonomi yang dimiliki Amerika Serikat telah membuat negara tersebut harus terus berupaya untuk mempertahankan eksistensinya dalam tatanan ekonomi dunia. Upaya tersebut dapat dilakukan dengan meningkatkan kegiatan perdagangan, khususnya sektor pertanian yang memberikan keuntungan besar bagi negara tersebut. Adapun produk pertanian yang menjadi prioritas utamanya adalah produk daging sapi.

Daging sapi menjadi salah satu komoditas unggulan di Amerika Serikat sehingga jumlah produksi produk tersebut cukup tinggi. Tercatat bahwa pada tahun 2016, produksi daging sapi Amerika Serikat mencapai 11,3 juta ton dan telah berkontribusi sebesar $19,25 \%$ pada produksi daging sapi dunia. Kondisi inilah yang kemudian membuat industri ini menjadi sektor yang paling memberikan keuntungan bagi kegiatan perdagangan Amerika Serikat.

Jumlah populasi masyarakat di Amerika Serikat yang selalu bertambah setiap tahunnya juga akan meningkatkan angka permintaan konsumen akan daging sapi. Hal ini akan membuat persediaan daging sapi dalam negeri pun tidak cukup sehingga masih perlunya mencari pemasok tambahan. Salah satu usahanya adalah dengan melakukan impor dari negara lain, seperti Kanada, yang telah cukup lama menjalin hubungan perdagangan bilateral dengan negara super power tersebut.

Berdasarkan data dari International Trade Center (2019), Kanada menjadi pemasok daging sapi terbesar bagi Amerika Serikat pada tahun 2009-2015, dengan total ekspor daging sapi sekitar lebih dari 150.000 ton. Terkait hal tersebut, Amerika Serikat harus selalu waspada dan mengawasi seluruh produk-produk impor yang masuk ke pasar mereka mengingat tingginya angka kematian di Amerika Serikat karena terkena penyakit Creutzfeldt-Jakob (CJD).

Penyakit CJD adalah gangguan otak degeneratif yang secara bertahap akan menghancurkan sel-sel pada otak dan membuat adanya lubang-lubang kecil pada otak. Indikasi seperti ini akan membuat adanya penurunan pada fungsi otak yang akan menyebabkan terjadinya demensia dan bahkan dapat berujung pada kematian. Penyakit CJD telah menjadi salah satu penyebab tingginya angka kematian di Amerika Serikat pada tahun 2009-2015 yang telah memakan korban sekitar 481 jiwa. Penyakit CJD sendiri dapat ditularkan melalui 3 cara, yaitu secara spontan, faktor keturunan, dan melalui kontaminasi oleh jaringan yang telah terinfeksi sebelumnya.

Dari ketiga faktor tersebut, USDA mengkonfirmasi bahwa tingginya angka kematian di tersebut karena banyaknya masyarakat yang mengkonsumsi daging sapi impor dari Kanada yang telah terkontaminasi oleh penyakit BSE atau sapi gila, yaitu penyakit fatal yang progresif pada sistem saraf sapi. Penyebab penyebaran ini ketika sapi diberikan makan bangkai hewan yang sebelumnya telah terinfeksi penyakit BSE atau sapi gila.

Kehadiran penyakit BSE atau sapi gila telah menimbulkan banyak kekhawatiran pada para importir daging sapi Kanada, khususnya Amerika Serikat. Menanggapi kondisi ini, maka Amerika Serikat mulai membatasi masuknya impor daging sapi Kanada demi kesehatan dan keamanan pangan negara tersebut dengan membentuk kebijakan Country of Origin Labelling (COOL), sebagai bentuk proteksi yang dilakukan oleh Amerika Serikat terkait adanya penyakit BSE atau sapi gila 
pada produk daging sapi impor dari Kanada. Jenis proteksi ini dikenal dengan istilah new protectionism yang menerapkan hambatan perdagangan non-tarif yang cenderung lebih tidak transparan.

Implementasi kebijakan COOL ini menjadi salah satu bentuk penyelewengan dalam perdagangan internasional karena adanya proteksi yang secara tidak langsung telah dilakukan oleh Amerika Serikat. Mengingat Amerika Serikat adalah negara super power, kondisi ini telah mengancam stabilitas suatu negara dan secara tidak langsung dapat menghambat tercapainya kepentingan nasional suatu negaranya sehingga dapat merusak mekanisme perdagangan internasional yang sejak dulu telah banyak berkontribusi dalam membangun sebuah negara.

\section{Hubungan Perdagangan Bilateral Kanada-Amerika Serikat Pasca Kebijakan Country Of Origin Labelling (COOL)}

Selama 30 tahun terakhir, Kanada dan Amerika Serikat terikat oleh perjanjian perdagangan bilateral yang disebut Canada-United States Free Trade Agreement (CUSFTA) yang telah menjadikan kedua negara berada digaris depan liberalisasi perdagangan. Selama ini, kedua negara menjalani kegiatan perdagangan yang saling menguntungkan satu sama lainnya. Hal tersebut dapat dilihat dari kedudukan Kanada sebagai importir barang Amerika Serikat terbesar senilai 18,3\% dari ekspor barang Amerika Serikat.

Di samping itu, Kanada juga merupakan eksportir barang terbesar ketiga dengan total $12,8 \%$ dari semua total impor barang Amerika Serikat. Perdagangan dua arah antara Kanada dan Amerika Serikat ini mewakili hampir 32\% dari PDB Kanada pada tahun 2017. Kondisi inilah yang membuat hubungan ekonomi kedua negara semakin ekstensif.

Meskipun begitu, beberapa penyelewengan masih kerap terjadi dalam pelaksanaan perdagangan kedua negara yang dapat memicu terjadinya pertentangan. Amerika Serikat sering kali membentuk kebijakan sepihak dan mendatangkan kerugian bagi pihak lainnya. Seperti yang terjadi pada kebijakan COOL Amerika Serikat yang bertujuan untuk membatasi dan mengurangi impor daging sapi dari Kanada yang terkontaminasi oleh penyakit BSE atau sapi gila.

Kebijakan tersebut telah mendiskriminasikan produk-produk impor atas produk lokal yang dilakukan secara eksplisit dengan memasukkan unsur nonperdagangan ke dalam persyaratan produk impor atau lebih dikenal sebagai bentuk proteksionisme baru yang dinamakan incidental protectionism, dimana penyakit BSE atau sapi gila digunakan oleh Amerika Serikat sebagai alat untuk membatasi impor daging sapi Kanada.

Implementasi kebijakan COOL ini tidak sejalan dengan komitmen Kanada dan Amerika Serikat yang telah disepakati dalam CUSFTA yang bertujuan untuk:

1. Menghilangkan hambatan untuk perdagangan barang dan jasa antara Kanada dan Amerika Serikat.

2. Memfasilitasi kondisi persaingan yang sehat dalam perdagangan bebas.

3. Secara signifikan meliberalisasikan kondisi untuk investasi. 
4. Menetapkan prosedur yang efektif untuk administrasi perjanjian dan penyelesaian sengketa bersama dan;

5. Meletakkan fondasi untuk kerjasama bilateral dan multilateral lebih lanjut untuk memperluas dan meningkatkan keuntungan dari perjanjian.

Berdasarkan tujuan CUSFTA tersebut, secara jelas Amerika Serikat telah melanggar tujuan utama perjanjian untuk menghilangkan segala macam bentuk hambatan dalam perdagangan. Adanya penyimpangan ini kemudian berpengaruh terhadap hubungan bilateral Kanada dan Amerika Serikat. Pasalnya sejak munculnya kebijakan COOL ini, arus perdagangan kedua negara menjadi terganggu.

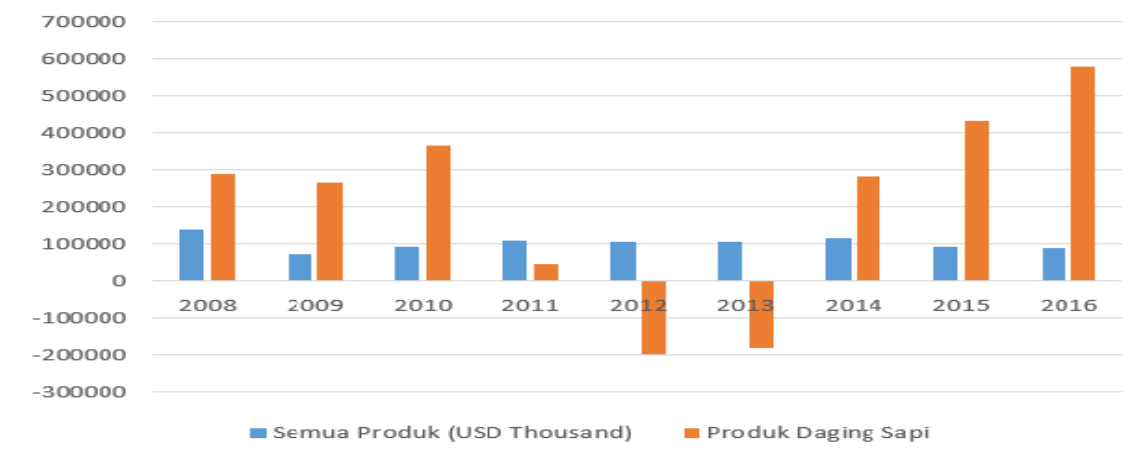

Gambar 1. Neraca Perdagangan Bilateral Kanada-Amerika Serikat Tahun 2009-2015

Berdasarkan grafik di atas, nilai neraca perdagangan bilateral Kanada dengan Amerika Serikat pasca kebijakan COOL tahun 2009-2015 mengalami kondisi yang tidak stabil, terutama pada produk daging sapinya. Neraca perdagangan Kanada atas produk daging sapi, terlihat pada grafik berwarna orange, mengalami perubahan yang signifikan pada tahun 2009 hingga 2015. Terlihat dari neraca perdagangan pada tahun 2010 sampai tahun 2013 mengalami penurunan nilai yang sangat drastis. Bahkan pada tahun 2012 dan 2013, neraca perdagangan Kanada mengalami defisit hingga mencapai lebih dari US\$150.000.

Adanya defisit neraca perdagangan ini tentunya menjadi suatu hal yang sangat tidak menguntungkan bagi Kanada, mengingat selama ini kedua negara memiliki sifat interdependensi yang cukup tinggi sehingga hal ini dapat menjadi sebuah kerugian jika sewaktu-waktu terjadi konflik antara kedua negara dalam perdagangannya. Kondisi inilah yang dialami oleh Kanada dengan adanya kebijakan COOL Amerika Serikat.

Sejak adanya kebijakan COOL, Kanada mendapatkan image yang tidak baik di mata dunia karena beberapa produk daging sapi negaranya terkontaminasi oleh penyakit sapi gila. Akhirnya banyak negara yang memutuskan untuk tidak menggunakan produk-produk Kanada untuk sementara waktu, berkurangnya jumlah investor asing, serta akan mengancam eksistensi perusahaan-perusahaan besar yang ada di Kanada. 
Selain itu, kebijakan COOL ini menyebabkan ketimpangan kepentingan yang terjadi pada kedua negara. Hal ini maka akan menghambat proses pemenuhan kebutuhan melalui kegiatan ekspor impor yang selama ini memiliki kontribusi paling besar bagi perekonomian kedua negara dan dapat mengancam posisi negaranegara tersebut sebagai salah satu negara dengan kekuatan ekonomi terbesar di dunia.

Guna meminimalisir kerugian lebih lanjut, Amerika Serikat harus mempertimbangkan kembali terkait penerapan kebijakan COOL dalam kegiatan perdagangan internasional dalam kondisi seperti ini, Amerika Serikat dituntut untuk bijak dalam membuat keputusan, mengingat negara tersebut memiliki pengaruh yang sangat besar terhadap negara-negara di dunia. Hal ini perlu dilakukan agar tidak ada pihak yang dirugikan dalam pelaksanaan perdagangan internasional.

\section{Ekspor Daging Sapi Kanada Pasca Kebijakan Country Of Origin Labelling (COOL)}

Keunggulan dalam faktor geografis, struktur tanah, dan sumber daya air yang melimpah di Kanada telah menjadikan negara tersebut sebagai salah satu produsen produk pertanian terbesar di dunia dan menjadi negara pengekspor produk pertanian (agri-food products) terbesar ke-5 di dunia. Tingkat produksi dan ekspor daging sapi menjadi komponen besar dan memberikan nilai tambah yang cukup tinggi terhadap pendapatan negara Kanada.

Pada tahun 2015, Kanada berhasil mengekspor dengan total lebih dari US\$ 1 juta produk daging sapi ke seluruh dunia. Hal tersebut didukung oleh banyaknya jumlah peternakan sapi yang ada di Kanada yang telah menyumbangkan sekitar $85 \%$ atas produk daging sapi potong bagi kegiatan perdagangannya.

Besarnya jumlah ekspor daging sapi Kanada juga ditunjang oleh tingginya tingkat konsumsi masyarakat atas produk daging sapi. Semakin tinggi tingkat konsumsi masyarakat akan produk daging sapi di suatu negara maka permintaan akan produk tersebut juga semakin banyak. Kondisi tersebut membuat pemerintah suatu negara akan semakin meningkatkan jumlah produksi sapi yang dapat menghasilkan daging sapi berkualitas.

Namun pada tahun 2009 hingga 2015, sektor pertanian Kanada sempat mengalami kemunduran dalam hal produksi dan juga pada aktivitas ekspor daging sapinya. Penurunan tersebut terjadi setelah CFIA secara resmi menyatakan adanya penyakit BSE atau sapi gila pada salah satu sapi yang lahir di Alberta Utara pada tahun 2009.

Dalam kasus ini, pemerintah Kanada, terutama para produsen sapi dalam negeri, merasakan beberapa dampak negatif yang telah menimbulkan ketidakstabilan kondisi dalam negerinya. Salah satu bentuk ketidakstabilan tersebut dapat dilihat dari jumlah persediaan sapi ternak yang ada di Kanada.

Berdasarkan data dari Statistic Canada, total produksi sapi ternak sejak tahun 2009 hingga 2015 mengalami penurunan sebesar 669 ekor. Angka penurunan produksi yang cukup tinggi tersebut dapat membahayakan kondisi negara Kanada kedepannya. Pasalnya, penurunan kuantitas sapi ternak tersebut telah menandakan bahwa telah terjadi penurunan pada performa peternak sapi di Kanada dalam 
memproduksi sapi sesuai dengan standar yang telah ditetapkan. Penurunan tersebut juga akan berpengaruh terhadap jumlah produk daging sapi berkualitas yang dihasilkan di negara tersebut.

Munculnya kasus BSE atau sapi gila ini secara perlahan telah menurunkan tingkat konsumsi masyarakat Kanada terhadap produk daging sapi lokal karena khawatir akan kesehatan dirinya sendiri sehingga memutuskan untuk mengurangi konsumsi atas daging sapi lokal hingga kasus BSE atau sapi gila berhasil diselesaikan dan seluruh produk daging telah dipastikan aman untuk dikonsumsi oleh publik.

Selain berdampak pada kondisi dalam negerinya, kasus ini juga telah membuat kondisi perdagangan internasionalnya mengalami pelemahan, terutama pada kegiatan ekspor daging sapinya. Beberapa negara mulai membatasi dan bahkan menghentikan impor daging sapi dari Kanada, salah satunya adalah Amerika Serikat. Pasca adanya kasus ini, Amerika Serikat mulai memperketat aturan-aturan terkait perdagangan produk pertaniannya. Hal tersebut direalisasikan dengan adanya kebijakan COOL yang mewajibkan para eksportir mencantumlan label negara asal produk mereka.

Kondisi tersebut tentunya membuat Kanada merasa dirugikan karena hadirnya kebijakan COOL itu akan membuat Kanada mengeluarkan biaya lebih untuk biaya produksi produk daging sapinya. Bahkan Kanada juga terancam akan kehilangan Amerika Serikat yang selama ini telah menjadi negara tujuan utama ekspor daging sapi negaranya akibat tingginya sifat interdependensi yang telah terjalin antara kedua negara.

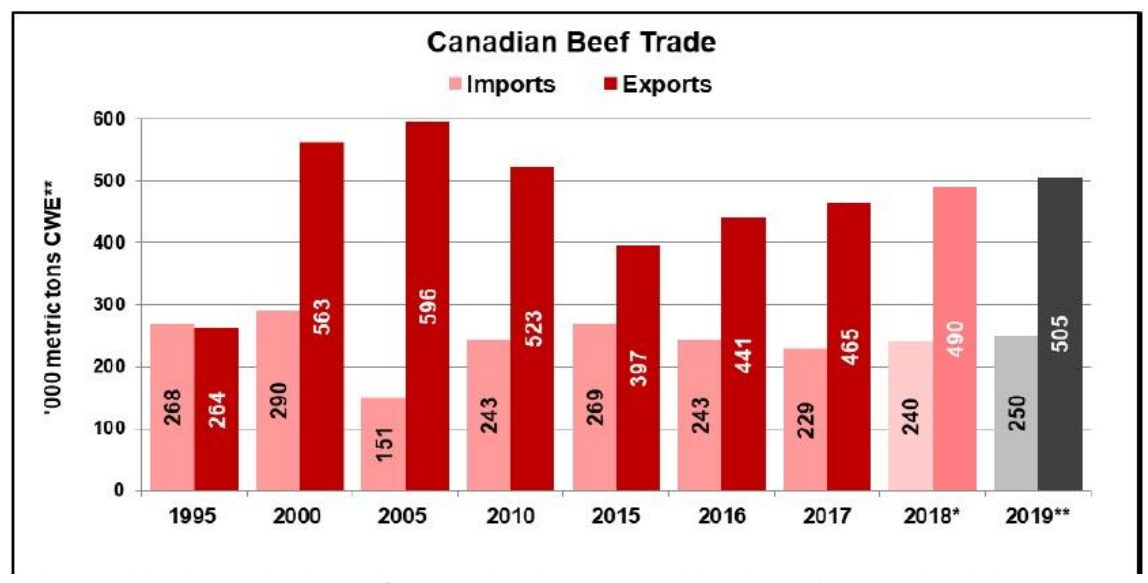

Gambar 2. Grafik Perdagangan Daging Sapi Kanada

Sesuai dengan grafik di atas terlihat bahwa jumlah ekspor daging sapi Kanada pada tahun 2000-an mengalami kondisi yang tidak stabil. Jika dibandingkan dengan periode lainnya, penurunan yang cukup signifikan terjadi pada tahun 2010 hingga 2015, tepat satu tahun ketika kebijakan COOL Amerika Serikat diberlakukan. Kuantitas ekspor daging sapi Kanada secara keseluruhan mengalami 
penurunan sebesar 126 tons. Jika hal ini terus terjadi maka neraca perdagangan Kanada akan menjadi tidak seimbang dan cenderung mengalami defisit. Selain itu, Kanada juga terancam akan kehilangan beberapa pangsa pasar terbesarnya dalam kegiatan ekspor impor daging sapi.

Sebagai negara yang bertumpu pada perdagangan produk daging sapi, Kanada harus bertindak secara cepat untuk mengatasi dampak negatif dari adanya kebijakan COOL tersebut demi menjaga kestabilan ekonomi negara dan demi menjaga mekanisme serta arus perdagangan daging sapi negaranya sehingga Kanada tetap mendapatkan posisi sebagai negara produsen daging sapi yang patut menjadi saingan berat negara-negara besar lainnya.

\section{Upaya Kanada Dalam Mengatasi Kebijakan Country Of Origin Labelling (COOL)}

Secara keseluruhan, munculnya kebijakan COOL ini telah membuat Kanada merasakan dampak ekonomi berupa output effects, yaitu dampak yang dihasilkan dari adanya perubahan permintaan untuk berbagai barang dan jasa dalam suatu daerah atau dari luar daerah. Hal ini dapat dilihat dari adanya penurunan permintaan dunia akan produk daging sapi pasca adanya kebijakan COOL tersebut sehingga membuat perekonomian Kanada mengalami defisit.

Mengingat pentingnya industri daging sapi inilah, maka Kanada harus memiliki sikap dan tindakan yang tegas untuk dapat bangkit dan menjaga stabilitas ekonomi serta arus ekspor daging sapi negaranya pasca diberlakukannya kebijakan COOL Amerika Serikat. Oleh karena itu, Kanada melakukan berbagai upaya sebagai berikut:

\section{Membentuk Mutual Recognition Agreements (MRA)}

Dalam upaya menyelesaikan masalahnya, Kanada dan Amerika Serikat sepakat untuk membentuk MRA atau perjanjian saling pengakuan antara pengekspor dan pengimpor. MRA ini akan membahas mengenai kesetaraan atas standarisasi produk impor yang akan masuk ke negara tujuan sehingga dapat meminimalisir adanya tindakan diskriminasi yang selama ini kerap menjadi masalah dalam perdagangan internasional.

Pembentukan MRA menjadi salah satu instrumen bagi Kanada untuk mencapai kepentingan nasionalnya dalam melakukan kegiatan perdagangan. Kepentingan pertama adalah terkait dengan hubungan perdagangan bilateral antara Kanada dan Amerika Serikat. MRA dapat menjadi langkah bagi kedua negara untuk memperbaiki hubungan perdagangan bilateralnya, dimana kedua negara dapat saling bernegosiasi dan menempatkan kepentingan nasional negaranya dalam perjanjian tersebut sehingga tidak akan ada lagi pihak yang dirugikan karena MRA dibentuk atas kesepakatan kedua belah pihak.

Kepentingan kedua adalah terkait dengan pasar daging sapi Kanada. Dengan adanya MRA, maka Kanada dan Amerika Serikat akan melakukan penyetaraan atas standarisasi produk yang akan terlibat dalam kegiatan ekspor dan impor kedua negara. Di sisi lain, Kanada juga dapat bernegosiasi dengan Amerika Serikat untuk 
dapat menghentikan publikasi mengenai produk impor daging sapi Kanada yang tidak sesuai standar.

Pembentukan MRA akan menciptakan stabilitas ekonomi dan pasar bagi kedua negara. Apabila dua kepentingan tersebut tercapai, maka mekanisme pasar pada kedua negara tersebut akan berjalan sebagaimana mestinya sehingga individu dalam masyarakat dapat melakukan aktivitas ekonomi dengan tenang tanpa adanya pihak yang dirugikan.

\section{Melakukan Re-Orientasi Pasar Ekspor Daging Sapi}

Hadirnya kebijakan COOL telah menimbulkan berbagai masalah terhadap hubungan bilateral Kanada dan Amerika Serikat. Kejadian ini menyebabkan Amerika Serikat mulai menutup dan mengurangi segala akses yang berhubungan dengan produk sapi Kanada. Akibatnya, produk daging sapi Kanada yang ingin masuk ke pasar Amerika Serikat dipersulit dengan berbagai aturan yang telah tertuang dalam kebijakan COOL tersebut.

Besarnya pengaruh yang dirasakan oleh Kanada ini juga membuat Kanada menjadi kehilangan target utama pasar daging sapinya sehingga kondisi ekspor daging sapi Kanada tahun 2009 hingga 2015 menjadi tertekan. Dengan adanya kejadian ini maka kepentingan nasional Kanada tidak dapat tercapai.

Tabel 1. Nilai Ekspor Daging Sapi Kanada ke Negara-Negara di Dunia (International Trade Center, 2016)

\begin{tabular}{|l|l|l|l|l|l|l|}
\hline & \multicolumn{7}{l}{ In Thousand US\$ } \\
\cline { 2 - 7 } & AS & Meksiko & Jepang & Taipei & Korea & Macau \\
\hline 2009 & 742,041 & 109,622 & 14,045 & 143 & 0 & 1,227 \\
\hline 2010 & 905,766 & 132,858 & 25,889 & 539 & 8 & 165 \\
\hline 2011 & 840,495 & 115,195 & 17,524 & 144 & 6 & 10 \\
\hline 2012 & 726,565 & 77,973 & 19,736 & 23 & 30 & 7 \\
\hline 2013 & 741,316 & 54,759 & 11,069 & 470 & 834 & 392 \\
\hline 2014 & $1,032,221$ & 91,345 & 14,956 & 4,692 & 2,860 & 67 \\
\hline 2015 & $1,057,165$ & 79,893 & 13,795 & 749 & 262 & 0 \\
\hline TOTAL & $6,045,569$ & 661,645 & 117,014 & 6,760 & 4,000 & 1,868 \\
\hline & In Tons & \multicolumn{5}{l}{} \\
\cline { 2 - 7 } & AS & Meksiko & Jepang & Taipei & Korea & Macau \\
\hline 2009 & 260,587 & 33,712 & 2,490 & 50 & - & 252 \\
\hline 2010 & 279,530 & 34,994 & 4,242 & 70 & 0 & 19 \\
\hline 2011 & 218,477 & 24,520 & 2,436 & 22 & 1 & 2 \\
\hline 2012 & 164,908 & 16,418 & 2,590 & 4 & 4 & 1 \\
\hline 2013 & 167,760 & 11,353 & 1,651 & 84 & 106 & 47 \\
\hline 2014 & 188,128 & 15,740 & 2,089 & 665 & 548 & 7 \\
\hline 2015 & 197,311 & 12,811 & 1,931 & 85 & 39 & - \\
\hline TOTAL & $1,476,701$ & 149,548 & 17,429 & 980 & 698 & 328 \\
\hline
\end{tabular}


Berdasarkan tabel 1 tersebut diatas, nilai ekspor daging sapi Kanada ke Amerika Serikat mengalami kondisi yang tidak stabil pada tahun 2009-2015, terutama pada tahun 2011 hingga 2013 yang mengalami penurunan cukup tajam sebagai dampak dari adanya kebijakan COOL. Melihat adanya penurunan ekspor daging sapi inilah, maka Kanada berinisiasi untuk melakukan re-orientasi pasar ekspor daging sapinya ke negara-negara lain.

Pencarian pasar baru tersebut dilakukan dengan melihat keunggulan komparatif (comparative advantage) dari produk daging sapi, kemudian didasari oleh opportunity cost yang diterima Kanada ketika memutuskan untuk beralih ke pasar ekspor daging sapi lainnya. Kanada akan mencari pasar yang menawarkan harga jual yang lebih tinggi dari Amerika Serikat.

Berdasarkan analisis yang telah dilakukan, pencarian harga rata-rata penjualan daging sapi Kanada per tons disesuaikan dengan data pada tabel 2. Harga penjualan daging sapi didapatkan dari proses pembagian antara total harga ekspor daging sapi Kanada (dalam USD) dengan banyaknya daging sapi yang di ekspor (dalam tons) sehingga didapatkan harga sebagai berikut:

Tabel 2. Harga Daging Sapi Kanada di Berbagai Negara (In Thousand USD Per Tons)

\begin{tabular}{|l|ll|}
\hline Amerika Serikat & USD 4.09 \\
\hline Meksiko & USD 4.42 \\
\hline Macau & USD $\quad 5.70$ \\
\hline Korea & USD $\quad 5.73$ \\
\hline Jepang & USD 6.71 \\
\hline Taipei & USD $\quad 6.90$ \\
\hline
\end{tabular}

Tabel 2 di atas memperlihatkan peluang keuntungan yang akan didapatkan oleh Kanada ketika akan mencari pasar ekspor daging sapi baru. Walaupun memutuskan untuk meninggalkan pasar daging sapi Amerika Serikat, Kanada dapat menemukan pasar ekspor daging sapi lain yang memiliki opportunity cost lebih rendah dibandingkan yang didapatkan dari pasar Amerika Serikat. Dari tabel tersebut, Kanada dapat memilih untuk mengekspor daging sapinya ke negara Meksiko (USD 4.42), Macau (USD 5.70), Korea (USD 5.73), Jepang (USD 6.71), dan Taipei (USD 6.90).

Jika dilihat dari target pasar barunya, maka Kanada akan melakukan reorientasi pasar ekspor daging sapinya ke Benua Asia, terutama Asia Timur, guna memperluas dan mencari keuntungan pada pasar ekspor daging sapinya.

Dengan memasarkan produk daging sapinya ke negara-negara tersebut, maka Kanada dapat meningkatkan nilai ekspor daging sapinya secara perlahan. 
Adanya pasar baru ini juga membuat sifat interdependensi Kanada dengan Amerika Serikat perlahan menurun karena Kanada mulai membuka diri untuk menerima dan bekerja sama dengan negara lain dalam kegiatan ekspor impor daging sapi. Upaya re-orientasi pasar ini juga menjadi strategi bagi Kanada untuk tetap dapat mencapai kepentingan nasionalnya melalui perdagangan atas produk daging sapi.

\section{SIMPULAN}

Dalam menjaga stabilitas ekspor daging sapinya pasca kebijakan COOL Amerika Serikat, Kanada memiliki dua upaya penyelesaian, yaitu dengan membentuk Mutual Recognition Agreement (MRA) dan mencari pasar ekspor daging sapi yang baru.

Inisiasi pembentukan MRA dilakukan oleh Kanada untuk dapat menyelesaikan permasalahannya dengan Amerika Serikat secara damai melalui negosiasi untuk melakukan penyetaraan atas standarisasi produk yang terlibat dalam kegiatan ekspor dan impor kedua negara. Upaya ini dilihat sebagai peluang yang sangat bagus untuk memperbaiki hubungan dagang antara Kanada dan Amerika Serikat karena selama proses pembentukan MRA ini, kedua negara dapat memasukkan kepentingan nasional negaranya masing-masing.

Selain itu, Kanada juga berupaya untuk mencari pasar ekspor daging sapi yang baru, selain Amerika Serikat, agar dapat terus melaksanakan perdagangan internasional yang berorientasi pada keuntungan. Upaya ini dilakukan Kanada dengan melihat keunggulan komparatif (comparative advantage) yang dimiliki oleh produk daging sapinya.

Lebih spesifik lagi, Kanada akan melakukan komparasi harga daging sapi dari berbagai negara dengan melihat biaya peluang (opportunity cost), dimana negara yang memiliki biaya peluang lebih rendah atau dengan kata lain memiliki harga jual yang lebih mahal maka dapat menjadi sasaran pasar baru bagi produk daging sapi Kanada. Negara-negara tersebut adalah Meksiko, Macau, Korea, Jepang, dan Taipei.

Melalui dua upaya tersebut, Kanada akan memiliki prospek yang baik ke depannya untuk dapat bangkit dari segala kerugian yang telah didapatkan dari adanya kebijakan proteksi Amerika Serikat berupa kebijakan COOL. Upaya tersebut juga diharapkan dapat menjadi langkah awal bagi kedua negara, bahkan negaranegara lain, untuk dapat melaksanakan perdagangan internasional secara tertib, baik ditingkat kawasan regional maupun global.

\section{DAFTAR PUSTAKA}

Agriculture and Agri-Food Canada. (2019). An Overview of the Canadian Agriculture and Agri-Food System 2016, di akses pada 2 Desember. http://www.agr.gc.ca/eng/about-us/publications/economic-publications/anoverview-of-the-canadian-agriculture-and-agri-food-system$2016 /$ id $=1462288050282$. 
Burchill, Scott. (2005). The National Interest in International Relations Theory, New York: Palgrave Macmillan.

Canada-United States Free Trade Agreement (CUSFTA).

Centers for Disease Control and Prevention. (2019). Creutzfeldt-Jakob Disease, Classic CJD : Occurrence and Transmission, di akses pada 28 Agustus. https://www.cdc.gov/prions/cjd/occurrence-transmission.html.

Centers for Disease Control and Prevention. (2019). BSE Cases Identified in Canadian-Born Cattle, di akses pada 20 April. https://www.cdc.gov/prions/bse/case-canadian-cattle.html.

International Trade Center, List of Importing Markets for a Product Exported by Canada - Product: 0201 Meat of Bovine Animals, Fresh or Chilled, di akses pada $10 \quad$ Desember 2019. https://www.trademap.org/Country_SelProductCountry_TS.aspx?nvpm=1\% 7c124\%7c\%7c\%7c\%7c0201\%7c\%7c\%7c4\%7c1\%7c1\%7c2\%7c2\%7c1\%7c $2 \% 7 \mathrm{c} 1 \% 7 \mathrm{c} 1$

Mill, John Stuart. (1885). Principles of Political Economy - with Some of Their Applications to Social Philosophy Volume I. New York: D. Appleton and Company. Di akses pada 12 Mei 2019. https://books.google.co.id/books/about/Principles_of_Political_Economy.ht $\mathrm{ml}$ ?id=1PBDF5zX1k8C\&printsec=frontcover\&source=kp_read_button\&red ir_esc $=\mathrm{y} \# \mathrm{v}=$ onepage $\& \mathrm{q} \& \mathrm{f}=$ false.

Ricardo, David. (1819). On the Principle of Political Economy and Taxation $\left(2^{\text {nd }}\right.$ Edition). John Murray. London.

Smith, Adam. (1976). The Wealth of Nation. Matheus.Co,Ltd. London.

The Perishable Agricultural Commodities Act of 1930.

United States Department of Agriculture. (2019). Country of Origin Labelling (COOL), di akses pada 20 April 2019. https://www.ams.usda.gov/rulesregulations/cool.

World Trade Organization. (2011). United States-Certain Country of Origin Labelling (COOL) Requirements. Report of the Panel WT/DS384/R and WT/DS386/R. 